\title{
EUROPEAN GREEN DEAL POLICY FOR THE CIRCULAR ECONOMY: OPPORTUNITIES AND CHALLENGES
}

\author{
Author(s): \\ K. Arta, Cs. Fogarassy
}

Affiliation:

Institute of Sustainable Development and Farming, Hungarian University of Agriculture and Life Science (MATE), 2100 Gödöllö, Páter Károly u. 1., Hungary

Email address:

Kuci.Arta@phd.uni-szie.hu, fogarassy.csaba@uni-mate.hu

\begin{abstract}
In December 2019, a European Green Deal was introduced to the EU and its community as a new development strategy by the European Commission (EC). The key goal of the European Green Deal is to reshape the EU into an ethical society with efficient use of resources and a modern-competitive economy. The European Commission targets an absolute reduction of greenhouse gases net emissions by 2050 in all EU. Thus, one of the most important actions in implementing this new growth strategy "EGD" is to coordinate the industry for a circular and clean economy. To reach this goal, EC introduced the most advanced legislation follow-up package that EU's society and businesses can benefit from. This legislation package includes actions and steps with a connecting guideline of principal policies, starting from a very determined goal in eliminating emissions, as well as investments in related innovation and research in order to protect the natural environment of Europe. However, reaching the goal of being the first among other continents to be climate- neutral by 2050 is so far the biggest challenge, as well as the greatest opportunity for Europe. In reality, in order to implement such advanced goals, obstacles need to be addressed as well, in national and international level. Thus, this paper analysis the European Green Deal (EGD) policy, the opportunities provided by EGD, and in particular the challenges faced for reaching the targets of EGD.
\end{abstract}

Keywords: New Growth Strategy, European Green Deal, Sustainability, European Commission, Circular Economy

\section{Introduction}

The European Union (EU) for decades has played a crucial role in formulating strategies to address climate change. It supported a climate change policy from 1992, and in 1996 approved the mission of reducing global warming by 2 degrees Celsius (Siddi, 2020). Later, in 2001, EU empowered its qualifications as a global ruler in tackling climate change after achieving sufficient supporters for adopting the Kyoto Protocol, although the United States had detached from it (Parker et al, 2017). Strong and determined internal policies supported the EU's international role and goal (Siddi, 2020). In this way, the EU established the ETS Emission Trading Scheme, which is the most fundamental trading scheme regarding greenhouse gas emissions and the supreme of EU's climate strategy (Kulovesi, 2017). After two years of the ETS establishment, EU approved broad and extensive climate legislation that contained the 20-20-20 aims (Siddi, 2020). However, although the global community failed in achieving an international understanding and agreement on reducing greenhouse emissions, EU still followed with working on its internal climate goals, as well as preparing and designing new targets for 2030 (Szulecki,2016). In 2015 the EU diplomacy achieved the Paris Climate Agreement, which furthermore inspired the Union to reconsider the energy efficiency, greenhouse emission reeducation, and renewable energy goals (Oberthür, 2019). However, in 2016, many major leaders, like as Jair Bolsonaro of Brazi, and Donald Trump in the United States have questioned and confronted EU and its global climate policies (Vihma, 2019). Yet, considering the climate crises around the world, the EU has followed to address climate policy as a prime issue (Siddi, 2020). In the same time, Ursula 
von der Leyen, as the head of the European Commission, on December 2019 has put the energy transition as one of EU's priority and declared that it will follow with a GREEN DEAL (European Commission, 2019).

Thus, in December 2019, a European Green Deal was introduced to the EU and its community as a new development strategy by the European Commission (EC). Great Deals are free-will and self-imposed consensus among different actors working jointly to expand sustainability and innovation. The European Green Deal can be view as an outline of crucial strategies for EU's climate policy, from which the EC will follow to establish legislative schemes and policies from 2020 and forth (Siddi, 2020). The main goal of the Green Deal outlook is to encourage movements in society through green projects and eliminate the obstacles for implementing them (Ganzevles et al, 2017). However, reaching the goal of being the first among other continents to be climate-neutral by 2050 is so far the biggest challenge as well as the greatest opportunity for Europe (Montanarella and Panagos, 2021). Thus, this paper analysis not only the opportunities provided by the European Green Deal but also the challenges faced for reaching the targets of EGD.

\section{Literature Review}

\section{Assessing the European Green Deal Policy}

For a while now, the society has been concerned with ecological and environmental matters in daily life, not only for the availability of water, sanitation and food, but also for the waste and green energy policies (Sikora, 2021). Hence, the European Commission presented the EGD proposal, an expanded legislation wrap with the goal of approaching climate change (Pianta and o Lucchese, 2020).The key goal of the European Green Deal is to reshape the EU into an ethical society with an efficient use of resources and a modern- competitive economy (Smol et al, 2020). Moreover, the European Commission through the European Green Deal aims to achieve a climate- neutral economy by eliminating carbon emission by minimum of fifty percent until 2030 and to reach a low-carbon future by the mid-century (Sikora, 2021). In particular, the mineral resources control has gained particular attention considering that EGD aims for economic growth which is limited due to inefficient resources management (EU, 2019). Thus, one of the most important actions in implementing this new growth strategy (EGD) is to coordinate the industry for a circular and clean economy (Toth, 2019). The circular economy and decarburization have captured a special attention as well, in particular in European Union which has been determined to be the prime of international energy transformation (European Council, 2019). The call for reducing greenhouse gas emissions and to reach carbon neutrality by 2050 has become a serious and urgent matter for lawmakers in Europe. Considering the special apprehensions regarding global warming, climate change and circular economy in particular, the EU has indicated its significant political engagement towards these issues by presenting various goals on renewable resources, energy efficiency, and GHG elimination (Hafner and Raimondi, 2020). According to Montanarella and Panagos (2021), these goals underline the principal concerns of EU. Nevertheless, some goals are easier to achieve than others. In reality, in order to implement such advanced goals, obstacles need to be addressed as well, in national and international level.

The European Unions has been actively giving attention and priority to actions against climate change. Various policies have been supported and adopted from EU in adopting sustainable energy, decreasing greenhouse gas emissions, as well as actively initiating global climate negotiation (Claeys et al, 2019). The European Green Deal is the latest policy for economic growth approved on late 2019 by the European Commission (Smol, et al, 2020). In this line, the EU president, Ursula von der Leyen, has assured to expand and reinforce the European climate policy (EU, 2019). In this context, the European Green Deal was proposed, which calls for climate neutral from EU by 2050- making Europe the first continent adopting this law (Claeys et al, 2019). According to Von der Leyen (2019) and Claeys et al, (2019), the European Green Deal outlines about 20 different schemes. These schemes aim to strengthen EU's 2030 goal on reducing emission up to 55 from 40 percent, presenting a carbon border tariff, developing a sustainable Europe Investment Plan, reshaping the EU Investment Bank from unsustainable banks, as well as creating a new industrial European strategy (EU 2019). However, achieving these targets requires the industry's mobilization for a circular and clean economy (Smol, et al, 2020).

According to Siddi (2020), the significance of climate policy by the new EU commission has been provided due to various factors: the climate crisis has become increasingly evident both in Europe and globally, as highlighted by repeated record high summer and winter temperatures, the melting of polar ice and glaciers, and highly mediatized events such as the catastrophic forest fires in Sweden, Siberia and Australia in 2018- 
2019. Ursula von der Leyen announced climate policy a main priority in the new EU commission on December 2019. This priority differs from the others in previous commissions as it positions the security of supply on a stronger significance and priority as a result of the tensions in Russia and the crisis in Ukraine in 2014 (Siddi,2020). Moreover, this policy related to the EU energy and climate regulation is built on three principal headline goals, a) enhancement in energy efficiency, (b) reduction on greenhouse emission, and (c) the production of final energy consumption from renewable energy (Directive 2018; Siddi, 2020).

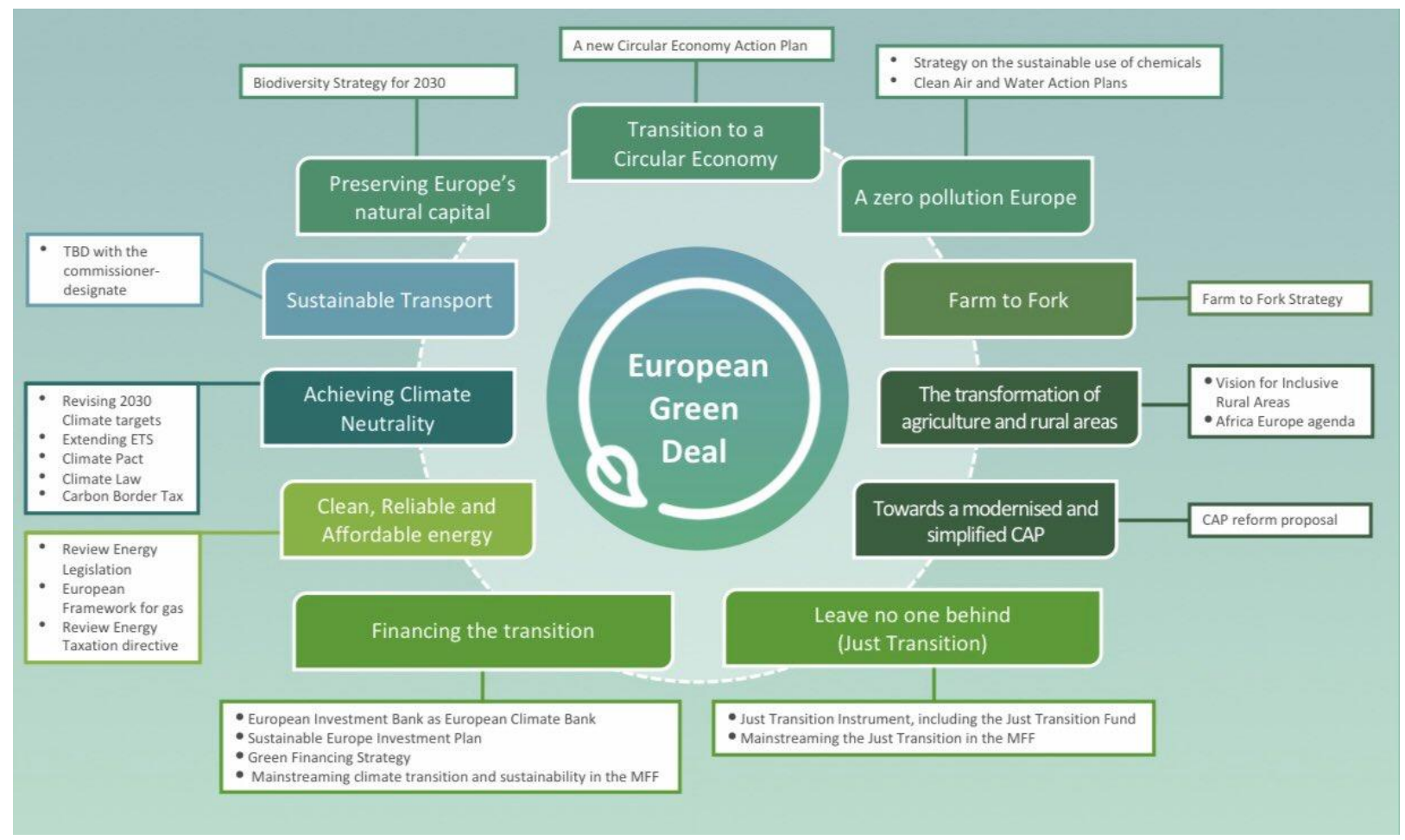

Figure 1. European Green Deal, Source: EUROCOOP (2020)

However, EU has failed to convincingly decrease greenhouse emissions, and not managed to fully address emission in some areas. Moreover, in Europe, growing concern about climate change was reflected in stronger electoral support for Green parties in the 2019 European elections, especially in some larger Western member states, as well as in the emergence of grassroots movements such as 'Fridays for Future' or 'Youth Strike for Climate (Siddi, 2020). The rise of climate change deniers such as Donald Trump in the US risked fatally undermining global cooperation on tackling climate change, as enshrined in the Paris Climate Agreement. All of these factors encouraged the Von der Leyen Commission to take the initiative and strengthen the Union's profile in global climate action (Siddi, 2020) In this line, the EU Commission expects to decrease the unwillingness of countries of Eastern and Central Europe, which have been resistant in environmental regulations considering that their business mainly rely on carbon (Lucchese and Nascia, 2016; Pianta and Lucche, 2020). Still, the most principal, aspiring and challenging target presented by the Commission is to reach zero net greenhouse gas (GHG) emissions by 2050 (Hafner and Raimondi, 2020). According to Block et al, (2020); Pianta and Lucche, (2020) there are crucial weakness that make EGD inadequate to convincingly approach Europe's climate change. Firstly, financing EDG could reach one trillion euro as a total amount over the ten next years, including Member States co-funding, EU and individual private funds (Piata and Lucche, 2020). Yet, regardless of succeeding in collecting such finances, this just amounts to a third of EU green investment gap to get to the climate goals until 2030 (Storm 2020, Clays et al, 2019). Second, EGD has poor strategy tools for increasing business's and government's willingness to comply with EDG's priorities (Figure 1.):

(i) they do not have a clear group of stimulators for investing in green manufacture;

(ii) Members States lack of executive restrictions that can make governments apply the EDG policies; and

(iii) there are no clear statement as to how could environmentally harmful public subsidies be removed (Pianta, Lucchese and Nascia 2020). 
Last, according to European Commission (2020), the Member States should provide 7.5 billion of fund to the "Just Transition Mechanism", so they could leverage 100 billion of private and public fund during the period 2021-2027. The total of this fund does not contemplate the resources required to guarantee the social transformation related to the climate change (Storm 2020; Pianta and Lucchese, 2020) Accordingly, the European Green Deal will be followed by a fund named "Just Transition Mechanism", whose task is to support regions and areas that rely mainly on carbon-concentrated operations (European Commission 2020; Pianta and Lucche, 2020), However, the success of the EU Green Deal relies on the stakeholder's effective and continuous commitment to accomplish the strategy (Yau, 2012, Camilleri 2020, Shawtari, Shamsudin, \& Hussain, 2018).

\section{Opportunities and Challenges implementing EGD}

\section{EGD Opportunities}

The overall goal of EU's Green Deal was to make the $27 \mathrm{EU}$ members achieve a low-carbon economy, with more health benefits, low air and water pollution, improved socio-economic aspects, and in general improved society's welfare. The EGD defined an aspiring framework of realizing 50-55\% reduction in GHG by 2030 and net-zero carbon emission by 2050 (European Commission, 2020a). Hence, the environment and economy do not necessarily dispute each other's functions. According to the green growth theory there can be a collaborating relationship between the economy and ecology by replacing and removing the parasitism of an environment-damaging industrial economy (Ossewaarde and Lowtoo, 2020). Thus, based on a green growth discourse, ecology preservation is a chance that yields high return investment, instead of pricey constrains (Bowen and Frankhauser, 2011; Loiseau et al., 2016; MacArthur, 2020). Increase in production, latest technologies, new materials, higher job possibilities and consumption increase are just few of the effects that the reconciled relationship between ecology and economy might provide to the economy (Ossewaarde and Lowtoo, 2020). However, regardless the fact that there is still some space for improvement regarding the Green Deal's proposal, yet it can greatly impact health improvement, as well as it could eliminate and minimize the growing health issues arising from globalization (Haines and $\mathrm{Eb}, 2019$ ). In order to achieve these health benefits it is required the application of adequate policy in sectors like, food industry, transport, health and energy sectors, which cause CO2 gas emissions and other climate pollutants (Haines, et al., 2009). The implementation of adequate policies can decrease air pollution, green gas emissions and O3, with great positive impacts in health. Moreover,, producing renewable energy instead of nonrenewable fuel source in these sectors would avoid around 4 million annually early deaths that are caused from heart and pulmonary chronic debases, stroke and other causes ( Haines and Scheelbeek, 2020).

In this regard, the rise of green sectors would not only provide ecological benefits but also health and economic ones, such as increasing green job possibilities and in general improving the standard and welfare of living (Sabato and Fronteddu ,2020) The international Labor Organization has also given attention to such benefits of green economy by stating that the green growth in economy could have impact on social advancement as well, considering its impact on green job creation (ILO, 2015). Moreover the energy efficiency is highly impacted from different environmental policies and regulations on local and international energy market (SIDDI, 2020); and the economic development and the society's welfare will be greatly improved through the cheap energy provided. In this regard, the negative effects resulted from poverty will be reduced (Cameron ET AL., 2020; Clayes and Tagliapietra, 2020; Deisenrieder et al., 2020) Moreover, the fast economic global development will increase the energy production for all areas of the economy. Considering that nowadays the advancement of the energy sector is created to boost the economic growth, it will support the competitiveness of all countries in the economic sector as well (European Conservatives and Reformists, 2020; Euractiv, 2020a; Euractiv, 2020b).

However, while the European Green Deal designs a general policy for sustainability, critical weaknesses affect the implementation of such strategy for global warming (Pianta and Lucchese, 2020).

\section{EGD Challenges}

The European Green Deal has anticipated around one trillion euros for financing as a general amount for the next 10 years, among which funds from the private sector are joint financed by the Member States and the EU funds. Considering that this amount might be reached by the EU, it still consists of just $1 / 3$ of the EU 
"environmental investment gap" in achieving climate goals for the next decade as appraised by the EU Commission (Claeys, Tagliapietra and Zachmann 2019; Storm 2020). The biggest part of this amount plays a role as an assurance from which bigger financial capital could be used in coordinating private funds in green production and technologies (Pianta and Lucchese, 2020). However, usually organizations hesitate in investing in processes that are of high risks and technologies are still in progress. In this regard, governments should step in and support such organizations with the "risk-reward nexus" concept - where government institutions should manage the allotment of high risk resources and socially required - environmental investments (Pianta and Lucchese, 2020) (Figure 2.)

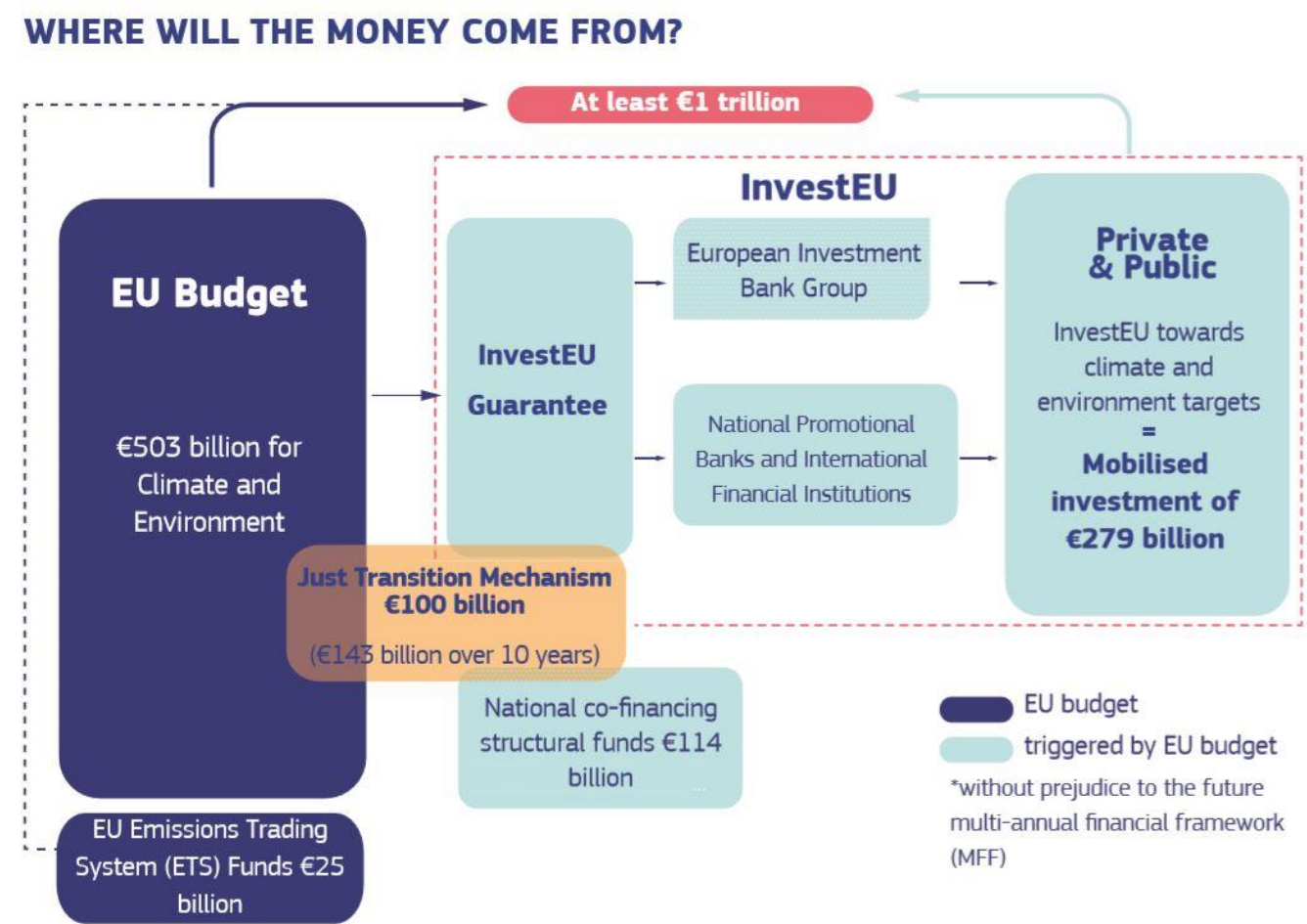

*The numbers shown here are net of any overlaps between climate, environmental and Just Transition Mechanism objectives.

Figure 2. EGD Budget, Source: European Commission (2020)

From the 1 trillion euro aimed for green investment, 100 billion Euro are required to be mobilized by the Just Transition Mechanism (JTM) by the period 2021-2027, in order to reduce the economic and social effect of the climate transition in regions whose activities and processes depend on fuel and coal chain (Parker, 2017). However, some experts argue that this amount will be mobilized by EU in order to rescue the banking industry from the economic crises occurred from 2008. They are also reluctant as to whether this amount declared by the EU is current and will it indeed be realized (Ringel and Knodt, 2018). Moreover they criticize that the JTM will transfer EU taxes to powerful upper-class locals whose business rely on decarburization, instead of allocating them to the main actors that were damaged from the fossil fuel processes (Schreurs, M., 2016). The EGD has poor strategy methods for stimulating governments and businesses to apply its agenda: companies have no transparent or clear stimulus for funding sustainable manufacturing (Pianta and Lucchese, 2020). Furthermore, Member States lack legal political restrictions that would stimulate state institutions to follow Green Deal's priorities (Karl and Schratzenstaller, 2016).In particular, the Green Deal agenda lacks clear proposal on how the price network will be adjusted, consisting of the price of $\mathrm{C} 02$-which has made businesses to follow up with unfriendly environmental actions (Pianta and Lucchese, 2020). Third, the EU Commission on itself admits that a wide EU industrial policy is needed for the European Green Deal Agenda (Karl and Schratzenstaller, 2016). However, the actual actions for industrial strategy continue to be limited in application and it is not clear as to if the EU regulations will be considered regarding the non - support state institutions towards companies which include green activities in their business (Clayes, 2019). 
Key challenges for a Green Industrial Policy

The evolution towards a green economy demands for structural modifications in production and technology processes. Thus, modern technologies have to be established entirely and the previous ones have to be restored (Altenburg and Rodrik 2017). Moreover the development and progress of economic structures requires investment in new technologies, establishing new manufacturing capacities, larger use of know-how and development of new socio-economic activities. To make this progress, the high economic and revenue disparities that have appeared in South-Eastern Europe countries should be taken into consideration (Pianta, Lucchese and Nascia, 2016). As a further challenge, there lacks a clear explanation as to how will the disparity, deindustrialization and climate change be approached, and with no clear vision of how an undivergenced and environmental friendly economy will arise in Europe. Thus, the evolution of this challenging climate direction delivers a huge part to public policies to address the green technology and developing new market possibilities (Lamperti et al., 2018).

Moreover, the Member States are required to provide 7.5 billion fund to the Just Transition Mechanism, while targeting a total of 100 billion private and public funds to be used from 2021-2027(European Commission, 2020). Yet, this total of fund does not manifest the capital that is required to guarantee society engagement in following with climate evolution (Storm 2020). Moreover there is no link whether and how the EGD may impact on repealing the socio-economic disparity among the" center" and "periphery" that have been spread in Europe in the last ten years (Pianta, Lucchese and Nascia, 2016). Nowadays, there is high inequality of capacities to increase resources for green investment and green technologies among EU countries and this new generator of disparity may continue to expand fragmentation and inequalities across Europe (Cleantech Group, 2017). In this matter, this progress towards industrial policy puts Europe before far-reaching challenges. Firstly, replacing the old technologies with new-modern ones can impact largely the workers, companies and markets among regions (Siddi, 2020).

Thus, the allocation of the costs and capital should be properly managed and successful adaptation policies should be implemented. Fuel, coal and other environmental damaging industries will require a considerable time of replacing the old technologies, which put state institutions in charge of addressing the transfer process (Euractiv, 2020c). Second, costs and prices will likely be affected and changed due to major modifications in energy sources; which will call for adequate methods to guarantee running competitiveness in regions with diverse energy mixes (Siddi, 2020). Such evolutions might expand divergences among companies that have it easier to shift into environmental friendly production due to their higher technological capacities - and companies that attain old technologies and fewer resources (Siddi, 2020). Polices have to aim expanding the system's production capacities simultaneously and motivate businesses to reach the higher environmental and technological standards (Altenburg and Assmann, 2017). Finally, modifications in productions, service and technology system could highly affect the number and quality of employment, salaries and capacities. Thus, policies should guarantee that employers receive the benefits of sustainability relating to higher salaries, employment and capacities, and ensuring that industrial divergences are reduced (Siddi, 2020). Moreover, the relation among EU national and local policies is another concern, which can play a huge role in approaching climate change. The concern is related in terms of how to develop strategies that consider the disparities between the capital, production and capacities among different countries and regions in EU (Bailey, Glasmeier and Tomlinson, 2019). Thus, public institutions could establish universal objectives for the green economy evolution; arrange an unanimity supporter between socio-economic performers and leaders; create the necessary knowledge jointly with universities and companies through establishing research technological divisions and establishing or reinforcing funding projects (Euractiv, 2020b). Finally, in order to acquire the positive impacts of an environmental friendly and unbiased economy, modifications in production structure should comply with relevant changes in social motilities and institutional environments (Perez, 2016). Broad- environmentally awareness progress in social relations, political actions, administration settings and private-public jointly practices are the strategies the goal of a greenenvironmental friendly Europe could be realized (Siddi, 2020).

Based on the literature review, the following correlations can be detected between the individual economic and policy program elements. The details of the SWOT analysis based on the processed literature are as follows. (SWOT stands for Strengths, Weaknesses, Opportunities, and Threats, and so a SWOT Analysis is a technique for assessing these four aspects of the analysed policy. We can use SWOT Analysis to make the most of what we've got, to our systems' best advantage.) (Table 1.) 
Table 1. Evaluation SWOT table about the Greed Deal program

\begin{tabular}{|c|c|}
\hline $\begin{array}{l}\text { Strengths: } \\
\text { - achieving climate policy goals } \\
\text { - start green, waste-free conversion } \\
\text { - maintaining economic growth } \\
\text { - increasing security of supply in material and } \\
\text { energy use }\end{array}$ & $\begin{array}{l}\text { Weaknesses: } \\
\text { - low level of innovation potential } \\
\text { - technical background and the unsuitability } \\
\text { of basic systems for green development in } \\
\text { underdeveloped parts of the EU } \\
\text { - various impediments to global economic } \\
\text { dependence }\end{array}$ \\
\hline $\begin{array}{l}\text { Opportunities: } \\
\text { - rapid opportunity for economic growth } \\
\text { - green transformation of lending and } \\
\text { investment programs } \\
\text { - a green insurance system can reduce } \\
\text { business risk } \\
\text { - implementation of a closed material cycle } \\
\text { instead of open waste streams }\end{array}$ & $\begin{array}{l}\text { Threats: } \\
\text { - growing regional disparities in } \\
\text { development } \\
\text { - energy price increase } \\
\text { - the sharpening of conflicts between energy } \\
\text { and climate policy interests }\end{array}$ \\
\hline
\end{tabular}

\section{Conclusion and Recommendations}

Various policies have been supported by EU in adopting sustainable energy, decreasing greenhouse gas emissions, as well as actively initiating global climate negotiation. The European Green Deal (GD) is the latest policy for economic growth approved in late 2019 by the European Commission, which calls for climate-neutral from EU by 2050- making Europe the first continent to adopt this law. However, achieving these targets requires the industry's mobilization for a circular and clean economy. To reach this goal, EC introduced the most advanced legislation follow-up package that EU's society and businesses can benefit from this green evolution.

Thus, the European Commission needs to assure the following:

(i) The supplementary allotment of funds for the GD is in fact added to the former budget, rather than a reorganization of funds realized previously;

(ii) The amount required for GD will not be mobilized by EU in order to rescue the banking industry from the economic crises that occurred from 2008;

(iii) EGD should follow up with a proposal on establishing legal political restrictions that would stimulate state institutions to follow Green Deal's priorities and a clear proposal on how the price system will be adjusted;

(iv) Policies should guarantee that employers receive the benefits of sustainability in regards of higher salaries, employment, and capacities, and ensuring that industrial divergences are reduced;

(v) Public institutions should be encouraged to establish universal objectives for the green economy evolution; arrange a unanimity supporter between socio-economic performers and leaders; create the necessary knowledge jointly with universities and companies through establishing research technological divisions and establishing or reinforcing funding projects ;

(vi) A clear proposal and vision as to how will the disparities, deindustrialization, and climate change be addressed;

The legislation package includes actions and steps with a connecting guideline of principal policies, starting from a very determined goal in eliminating emissions, as well as investments in related innovation and research in order to protect the natural environment of Europe. However, reaching the goal of being the first among other continents to be climate-neutral by 2050 is so far the biggest challenge, as well as the greatest opportunity for Europe. In reality, in order to implement such advanced goals, obstacles need to be addressed as well, in national and international level.

\section{Acknowledgement}

Special thanks to the National Research, Development and Innovation Office - NKFIH (Program ID: OTKA 131925). 


\section{References}

[1] Aicja Sikora (2021) European Green Deal - legal and financial challenges of the climate change. ERA Foruma, 21, 681-697.

[2] Bowen, A.; Frankhauser, S. (2011) The green growth narrative: Paradigm shift or just spin? Global Environ. Chang, 21(4), 1157-1159.

[3] Block, Fred, Matthew R. Keller and Marian Negoita (2020) Network failure and the evolution of the US innovation system. Journal of Industry, Competition and Trade, 20 (02), 235-247.

[4] Cameron, A., Claeys, G., Midões, C. and Tagliapietra, S. (2020) 'How good is the European Commission's Just Transition Fund proposal?', Bruegel Policy Contribution 4. https://www.bruegel.org/wp-content/uploads/2020/02/PC-04_2020-V2.pdf.

[5] Claeys, G. and Tagliapietra, S. (2020) 'A trillion reasons to scrutinise the Green Deal Investment Plan’, Bruegel, 15 January. https://www.bruegel.org/2020/01/a-trillion-reasonsto-scrutinise-thegreen-deal-investment-plan/.

[6] Deisenrieder, V., Kubisch, S., Keller, L., and Stötter, J. (2020) 'Bridging the Action Gap by Democratizing Climate Change Education-The Case of k.i.d.Z.21 in the Context of Fridays for Future', Sustainability, 12(5), 1-19.

[7] EUROCOOP (2020) DIGEST: Green Deal \& Farm to Fork Strategy, EUgreendeal, https://www.eurocoop.coop/news/282-DIGEST-Green-Deal-and-Farm-to-Fork-Strategy.html

[8] European Commission (2019) The European Green Deal, COM 640 final, 11 December. https://ec.europa.eu/info/sites/info/files/european-green-deal-communication_en.pdf.

[9] European Commission (2020). Sustainable Europe Investment Plan/European Green Deal investment plan. Communication from the commission to the European Parliament, the European Council, the Council, the European Economic and Social Committee and the Committee of the Regions 21.

[10] European Conservatives and Reformists (2020) 'Legal opinion: Green Deal delegated acts are incompatible with EU Treaties', 2 April.

https://ecrgroup.eu/article/legal_opinion_green_deal_delegated_acts_are_incompatible_w ith_eu_treaties.

[11] Euractiv (2020a) 'EU's next top climate model under scrutiny', 5 March. https://www.euractiv.com/section/climate-environment/news/eus-next-top-climatemodel-underscrutiny/.

[12] Euractiv (2020b) 'EU's draft climate law leaves 2030 target up in the air', 3 March.https://www.euractiv.com/section/energy-environment/news/leak-eus-draft-climatelawleaves-2030-target-up-in-the-air/.

[13] Grégory Claeys, Simone Tagliapietra and Georg Zachmann (2019) How to make the European Green Deal work. Policy Contribution, 14, 2-21.

[14] Haines, A. and K. Ebi (2019) The imperative for climate action to protect health. New England Journal of Medicine, 380(3): p. 263-273.

[15] Haines, A., et al.: (2009) Public health benefits of strategies to reduce greenhouse-gas emissions: overview and implications for policy makers. The Lancet, 374, 2104-2114.

[16] Hafner, Pier Paolo Raimondi (2020) Priorities and challenges of the EU energy transition: From the European Green Package to the new Green Deal. Russiam Journal of Economics 6(4); 374-389.

[17] ILO (2015) Guidelines for a just transition towards environmentally sustainable economies and societies for all, Geneva, ILO.

[18] Jurgen Ganzevles, José Potting and Aldert Hanemaaijer (2017) Evaluation of Green Deals for a Circular Economy. PBL netherlands Environmental Assessment Agency, 2-15.

[19] Kulovesi, K. (2017) EU Emissions Trading Scheme: preventing carbon leakage before and after the Paris Agreement, in Leal-Arcas, R. (ed.) Research handbook on EU energy law and policy. Cheltenham: Edward Elgar, 417-431.

[20] Karl Aiginger (2016) "New Dynamics for Europe: Reaping the Benefits of Socio-ecological Transition Part I: Synthesis. WWW for Europe Deliverable No. 11," WIFO Studies, WIFO, number 58791, December.

[21] Lindberg, M. B. (2019) The EU Emissions Trading System and Renewable Energy Policies: Friends or Foes in the European Policy Mix? Politics and Governance. 7(1): 105-123. 
[22] K. Pitkänen, R. Antikainen, N. Droste, E. Loiseau, L. Saikku, L. Aissani, B. Hansjürgens, P. J. Kuikmanf, P. Leskinen, M. Thomsen (2016) What can be learned from practical cases of green economy? -studies from five European countries. Journal of Cleaner Production, 139, 666-676.

[23] Luca Montanarella and Panos Panagos (2020) The relevance of sustainable soil management within the European Green Deal. Land Use Policy, 100, 1-6.

[24] Marzena Smol, Paulina Marcinek, Joanna Duda and Dominika Szołdrowska (2020) Importance of Sustainable Mineral Resource Management in Implementing the Circular Economy (CE) Model and the European Green Deal Strategy. Management, Environment, Energy and Sustainability under a Circular Economy, 9 (6), 78.

[25] Marco Siddi (2020) The European Green Deal: Assessing its current state and future implementation. Finish Institute of International Affairs, 4-13.

[26] Mark Anthony Camilleri (2020) European environment policy for the circular economy: Implications for business and industry stakeholders. Sustainable Development, 28 (06), 1804-1812.

[27] Mario Pianta and Matteo Lucchese (2020) Rethinking the European Green Deal: An Industrial Policy for a Just Transition in Europe. Review of Radical Political Economics. 52 (4), 633-641.

[28] MacArthur, J.L., Hoicka, C.E., Castleden, H., Das, R., Lieu, J. (2020) Canada's green new deal: Forging the socio-political foundations of climate resilient infrastructure Energy Research \& Social Science., 65, 2214-6296.

[29] Oberthür, S. (2019) Hard or Soft Governance? The EU's Climate and Energy Policy Framework for 2030. Politics and Governance. 7, 1: 17-27.

[30] Ossewaarde, M. and Ossewaarde-Lowtoo, R. (2020) The EU's Green Deal: A Third Alternative to Green Growth and Degrowth?. Sustainability, 12 (23), 1-15.

[31] Parker, C. F., Karlsson, C. and Hjerpe, M. (2017) Assessing the European Union's global climate change leadership: from Copenhagen to the Paris Agreement. Journal of European Integration. 39, 2: 239-252.

[32] Pianta M, Lucchese M. (2020) Rethinking the European Green Deal: An Industrial Policy for a Just Transition in Europe. Review of Radical Political Economics, 52 (4):633-641.

[33] Ringel, M. and Knodt, M. (2018) 'The governance of the European Energy Union: Efficiency, effectiveness and acceptance of the Winter Package 2016', Energy Policy, Vol. 112, pp. 209-220. 22.

[34] Schreurs, M. (2016) 'The Paris Climate Agreement and the Three Largest Emitters: China, the United States, and the European Union', Politics and Governance, Vol. 4, Issue 3, pp. 219-223.

[35] Szulecki, K. (2016) European energy governance and decarbonization policy: learning from the 2020 strategy. Climate Policy. 16, 5: 543-547.

[36] Salem, M. A., Shawtari, F., Shamsudin, M. F., \& Hussain, H. B. I. (2018). The consequences of integrating stakeholder engagement in sustainable development (environmental perspectives). Sustainable Development, 26 (3), 255-268.

[37] Servaas, Storm (2020) The EU's Green Deal: Bismarck's "what is possible" versus Thunberg's "what is imperative". Institute for New Economic Thinking, 117, 2-31.

[38] Sebastiano Sabato and Boris Fronteddu (2020) A socially just transition through the European Green Deal? european trade union institute, :1-42.

[39] Tóth, G. Circular Economy and its Comparison with 14 Other Business Sustainability Movements. Resources 2019, 8 (4), 1-19.

[40] Vihma, A. (2019) What's next for UN climate negotiations? The UNFCCC in the era of populism and multipolar competition. FIIA Briefing Paper 257, 1795-8059.

[41] von der Leyen, Ursula (2019) 'A Union that strives for more: My agenda for Europe', Political Guidelines for the Next European Commission 2019-2024, available at https://ec.europa.eu/commission/sites/ beta-political/fi les/political-guidelines-nextcommission_en.pdf.

[42] Yau, Y. (2012). Stakeholder engagement in waste recycling in a high-rise setting. Sustainable Development, 20 (2), 115-127. 